\title{
Thyroid hormones profile in students of Makerere College of Health Sciences in Kampala Uganda
}

\author{
H. DIKA ${ }^{1,2}{ }^{*}$, J. KASOLO 2 and G. BIMENYA ${ }^{2}$ \\ ${ }^{1}$ Department of Physiology, Weill Bugando University College of Health Sciences, Saint Augustine University \\ of Tanzania, P.O. Box 1464, Mwanza, Tanzania \\ ${ }^{2}$ Makerere College of Health Sciences, Makerere University, P.O. Box 7072, Kampala, Uganda
}

\begin{abstract}
Serum concentrations of thyroxine (T4), triiodothyronine (T3) and Thyroid Stimulating Hormone (TSH) are used to assess thyroid function. It is recommended that each laboratory or hospital should establish its own reference values of T4, T3 and TSH for their clients because these hormones vary with ethnicity, geographical and climatic conditions of a population. There is no documented study which has been done to determine the Thyroid hormones profile in Ugandan general population. This study is one of the first attempts to determine Thyroid hormones profile in healthy Ugandans. The main objective of this study was to determine the thyroid hormones profile of students of the Makerere College of Health Sciences in Kampala, Uganda. A cross sectional descriptive study was done involving 72 students, with the mean age of $24.17 \pm 4.48$ years. Subjects who volunteered to participate in the study were interviewed; their height and body weight measured, $5 \mathrm{ml}$ of blood withdrawn, and sera harvested. FT4 and T3 Radioimmuno Assay (RIA) were done and TSH was assayed using Immunoradiometric Assay (IRMA) technique. The mean serum concentration of FT4 was $17.016 \pm 3.847 \mathrm{Qmol} / \mathrm{L}$. For T3, mean serum concentration was $1.43 \pm 0.825$ $\mathrm{nmol} / \mathrm{L}$, and mean serum TSH level was $2.412 \pm 2.284 \mu \mathrm{IU} / \mathrm{ml}$. Variations of serum concentrations of FT4, T3 and TSH with sex, age, or region of origin were not statistically significant. Serum concentration of TSH increased with increased body mass index (BMI). It was $2.073 \pm 1.907 \mu \mathrm{IU} / \mathrm{ml}$ for subjects with BMI of $\leq 24.9 \mathrm{Kg} / \mathrm{m}^{2}, 3.588 \pm 1.495 \mu \mathrm{IU} / \mathrm{ml}$ for subjects with BMI of $25-29.9 \mathrm{~kg} / \mathrm{m}^{2}$ and $4.450 \pm 0.593 \mu \mathrm{IU} / \mathrm{ml}$ for subjects with $\mathrm{BMI} \geq 30 \mathrm{~kg} / \mathrm{m}^{2}(P=0.009)$. However, BMI had no effect on serum concentrations of FT4 and T3. Serum concentrations of T4, T3 and TSH obtained from this study all differ with the values which are currently used as reference ranges in the country. We recommend a similar study involving a population representative of Ugandans to be conducted so as to establish normal reference values of T4, T3 and TSH for Ugandans. We also recommend BMI of patients to be taken into consideration during interpretation of serum TSH concentrations results.
\end{abstract}

Key words: Thyroxine, triiodothyronine, Thyroid Simulating Hormone, university students, Uganda

\section{Introduction}

The two principal biologically active thyroid hormones, thyroxine (T4) and triiodothyronine (T3) together with Thyroid Stimulating Hormone (TSH) are used to assess thyroid function Thyroid function tests are used in a variety of clinical settings to assess integrate of the thyroid gland and monitor the treatment of hyper and hypothyroidism.

It has been recognized for some time that levels of thyroid function parameters in healthy subjects show considerable inter-individual variability leading to wide (populationbased) laboratory reference ranges, whereas intra-individual variability has a much narrower range (Andersen et al., 2002 ). Since thyroid function vary with ethnicity, geographical and climatic conditions, it is recommended that each laboratory or hospital establishes its own reference values of T4, T3 and TSH serum concentrations for their clients

\footnotetext{
${ }^{*}$ Correspondence: Dr. Haruna Dika; E-mail : hdika2001@yahoo.co.uk
} 
(Institute of Isotopes Company Ltd, Budapest. http://www.izotop.hu). Otherwise, choosing unrelated "normal ranges" may lead to a false diagnosis. This is important because clinical management of thyroid conditions depends very much on estimations of serum TSH, T4 and $\mathrm{T} 3$ in relation to the reference range. Many times given abnormal values for a given individual may not necessarily be abnormal but misinterpreted according to the designated reference range.

Furthermore, there is increasing evidence that at the population level, small differences in thyroid function are associated with differences in clinically important parameters such as body mass index (BMI) (Knudsen et al. 2005). As different populations can have specific basal metabolic rate due to various climatic conditions and various genetic make-ups, variation in the mean plasma concentrations of $\mathrm{T}_{4}, \mathrm{~T}_{3}$ and TSH is obvious (Reed 2000). Although the distribution of the mean serum concentrations of $\mathrm{T}_{4}, \mathrm{~T}_{3}$ and TSH in the various populations shows normal distribution curves, this continuous variation fluctuate because of variations in the living conditions and genetic profile (Meikle et al. 1988).

Unfortunately, there is no known study done to determine the Thyroid hormones profile in healthy Ugandans. The currently used normal references for normal ranges of serum concentrations of $\mathrm{T}_{4}, \mathrm{~T}_{3}$ and $\mathrm{TSH}$ in Uganda, are those set in the Caucasian population, which may not be normal for the Ugandan population. This study therefore was carried out to document T4, T3 and TSH levels for students in Makerere College of Health Sciences in Kampala, Uganda. The findings can serve as reference values for adult Ugandans.

\section{Materials and Methods}

\section{Study subjects}

A cross sectional descriptive study was done to determine the Thyroid hormones profile of students in Makerere College of Health Sciences of Makerere University, Kampala, Uganda. The study involved male and female students who voluntarily agreed to participate in the study. Non-Ugandan students and those with history of or symptoms and/signs of thyroid diseases were excluded from the study. Students using steroids orally were also excluded. A consecutive sampling procedure was used to include subjects that met the selection criteria. To ensure that the subjects selected were representative of students of Makerere College of Health Sciences, about equal proportions $(6.3-7.0 \%)$ of subjects from each class were recruited for study.

\section{Data collection}

The participants were given self-administered questionnaires to provide information on demographic characteristics. Height in the nearest centimetre was measured using a height ruler; and weight in the nearest gram was measured using analog person weighing scale. Body Mass Index (BMI) was computed as weight in kilograms divided by the height in meters squared.

Blood samples were obtained, centrifuged and sera harvested. The sera were stored at $-20^{\circ} \mathrm{C}$ and analyzed within three days. Serum free T4 (FT4) and T3 were determined by radioimmunoassay (RIA), while serum TSH was determined by immunoradiometric assay (IRMA). The RIA and IRMA kits were bought from Institute of Isotopes Company Ltd of Budapest, Hungary. 


\section{Ethical considerations}

The study was approved by Makerere College of Health Sciences Research and Ethics Committee on behalf of Ugandan National Council for Sciences and Technology. All participants gave written informed consent.

\section{Data analysis}

Data was analysed with SPSS version 11.0. The relationships between serum concentrations of FT4, T3 and TSH; and age, region of origin and BMI were determined using one way ANOVA. Association of hormone levels with sex was determined by Student's t-test. Statistical significance level was fixed at $\mathrm{p}<0.05$.

\section{Results}

A total of 72 Ugandan students aged 19 - 37 years were recruited in the study. Their mean age was $24.17 \pm 4.48$ years. Forty two $(58.3 \%)$ of the subjects were males and $30(41.7 \%)$ were females. Majority (48.6\%) of the subjects were from central region; 10 (13.9\%) were from northern, 12 (16.7\%) from eastern and 15 (20.8\%) were from western region. Only 1 student $(1.4 \%)$ was underweight (BMI $\left.<18.5 \mathrm{~kg} / \mathrm{m}^{2}\right)$. Majority, $58(80.6 \%)$ who had normal BMI of 18.5 $\leq 24.9 \mathrm{~kg} / \mathrm{m}^{2}$ and $10(13.9 \%)$ were overweight (BMI $\left.25-29.9 \mathrm{~kg} / \mathrm{m}^{2}\right)$. Only $3(4.2 \%)$ were obese $\left(\mathrm{BMI} \geq 30 \mathrm{Kg} / \mathrm{m}^{2}\right)$.

Table 1: Mean serum concentrations of FT4, T3 and TSH by Age

\begin{tabular}{llll}
\hline Age (years) & FT4 $($ omol/L) & T3 $(\mathbf{n m o l} / \mathrm{L})$ & TSH $(\mu \mathrm{IU} / \mathbf{m l})$ \\
\hline$\leq 20$ & $17.87 \pm 4.063$ & $1.31 \pm 0.879$ & $2.71 \pm 2.404$ \\
$21-25$ & $17.83 \pm 4.243$ & $1.45 \pm 0.812$ & $2.45 \pm 2.259$ \\
$26-30$ & $15.24 \pm 2.916$ & $1.62 \pm 0.788$ & $2.24 \pm 2.056$ \\
$31^{+}$ & $15.59 \pm 1.882$ & $1.99 \pm 0.536$ & $1.84 \pm 1.328$ \\
P- value & 0.077 & 0.091 & 0.817 \\
\hline
\end{tabular}

The mean serum concentration of FT4 was $17.016 \pm 3.847$ @mol/L. For T3, mean serum concentration was $1.43 \pm 0.825 \mathrm{nmol} / \mathrm{L}$, and mean serum TSH level was $2.412 \pm 2.284 \mu \mathrm{IU} / \mathrm{ml}$. There was no statistically significant difference in mean serum concentrations of FT4, T3 and TSH between males and females. The variations of levels of these hormones with age were not statistically significant (Table 1). There was no relationship between serum concentrations of these hormones with region of origin (Table 2).

Table 2: Mean serum concentrations of FT4, T3 and TSH by Region of Origin

\begin{tabular}{llllll}
\hline \multirow{2}{*}{$\begin{array}{l}\text { Mean } \\
\text { concentration of }\end{array}$} & Central & Northern & Eastern & Western & P value \\
& & & & & \\
\hline FT4 $(\mathrm{Omol} / \mathrm{L})$ & $16.97 \pm 4.14$ & $16.52 \pm 3.76$ & $15.77 \pm 2.18$ & $18.35 \pm 4.01$ & 0.389 \\
$\mathrm{~T} 3(\mathrm{nmol} / \mathrm{L})$ & $1.32 \pm 0.77$ & $1.26 \pm 0.86$ & $2.01 \pm 0.94$ & $1.43 \pm 0.77$ & 0.061 \\
$\mathrm{TSH}(\mu \mathrm{IU} / \mathrm{ml})$ & $1.86 \pm 1.17$ & $3.57 \pm 3.13$ & $3.39 \pm 3.09$ & $2.13 \pm 1.73$ & 0.107 \\
\hline
\end{tabular}

Serum concentration of TSH increased with increased BMI (Table 3). It was $2.073 \pm 1.907$ $\mu \mathrm{IU} / \mathrm{ml}$ for subjects with BMI of $\leq 24.9 \mathrm{Kg} / \mathrm{m}^{2}, 3.588 \pm 1.495 \mu \mathrm{IU} / \mathrm{ml}$ for subjects with BMI of $25-29.9 \mathrm{~kg} / \mathrm{m}^{2}$ and $4.450 \pm 0.593 \mu \mathrm{IU} / \mathrm{ml}$ for subjects with BMI $\geq 30 \mathrm{~kg} / \mathrm{m}^{2}(P=0.009)$. FT4 
decreased with increased BMI. It was $17.435 \pm 3.954$ omol/L for subjects with $<25 \mathrm{Kg} / \mathrm{m}^{2}$, $16.024 \pm 2.931 \mathrm{gmol} / \mathrm{L}$ for subjects with $25-29.9 \mathrm{~kg} / \mathrm{m}^{2}$ and $12.365 \pm 1.020 \mathrm{omol} / \mathrm{L}$ for subjects with $\geq 30 \mathrm{Kg} / \mathrm{m}^{2}$. However this relationship was not statistically significant (Table 3). Serum T3 levels, increased with increased BMI, though the relationship was not statistically significant (Table 3). It was $1.360 \pm 0.812 \mathrm{nmol} / \mathrm{L}$ for subjects with $<25 \mathrm{~kg} / \mathrm{m}^{2}, 1.531 \pm 0.930$ $\mathrm{nmol} / \mathrm{L}$ for subjects with $25-29.9 \mathrm{Kg} / \mathrm{m}^{2}$ and $2.335 \pm 0.589 \mathrm{nmol} / \mathrm{L}$ for subjects with $\geq 30$ $\mathrm{kg} / \mathrm{m}^{2}(P=0.253)$.

Table3: Mean serum concentrations of FT4, T3 and TSH by BMI

\begin{tabular}{lllll}
\hline $\begin{array}{l}\text { Mean serum } \\
\text { concentration of }\end{array}$ & \multicolumn{3}{c}{ BMI $\left(\mathbf{k g} / / \mathbf{m}^{2}\right)$} & P value \\
& $\leq \mathbf{2 4 . 9}$ & $\mathbf{2 5 - 2 9 . 9}$ & $\mathbf{2 3 0}$ & \\
\hline $\mathrm{FT} 4(\mathrm{Omol} / \mathrm{L})$ & $17.435 \pm 3.954$ & $16.024 \pm 2.931$ & $12.365 \pm 1.020$ & 0.124 \\
$\mathrm{~T} 3(\mathrm{nmol} / \mathrm{L})$ & $1.360 \pm 0.812$ & $1.531 \pm 0.930$ & $2.335 \pm 0.589$ & 0.253 \\
$\mathrm{TSH}(\mu \mathrm{IU} / \mathrm{ml})$ & $2.073 \pm 1.907$ & $3.588 \pm 1.495$ & $4.450 \pm 0.593$ & $0.009^{*}$ \\
\hline
\end{tabular}

* Statistically significant

\section{Discussion}

Although the mean serum concentration of FT4 was comparable to $17.5 \pm 4.8 \mathrm{pmol} / \mathrm{L}$ found by Samollow et al.(2004) and higher than $14.83 \pm 2.2 \mathrm{omol} / \mathrm{L}$ found by Institute of Isotopes Company Ltd among healthy blood donors in Hungary, the T3 level was slightly lower than those found by the same studies. The mean TSH level was comparable to that reported by Hollowell et al. (2002) for the Mexican-American" disease-free" population and that obtained by Samollow et al. (2004). Other studies found TSH to vary from $0.4-4.2 \mu \mathrm{IU} / \mathrm{ml}$ (Nelson et al., 1993; Fisher, 1996).

Differences between the results from this study and the reference values which are currently being used in Uganda laboratories are accounted for by race, age of subjects and climatic condition. In this study, all the study subjects were black Africans, while the healthy blood donors used by Institute of Isotopes were Caucasians. Subjects in this study aged $19-$ 37 years, with a mean age of $24.17 \pm 4.48$ year, while the subjects used by Institute of Isotopes Company Ltd aged from 19-69 years, with a mean age of $33.4 \pm 11.7$ years. This study was conducted in Uganda which is in the tropics, and the climate differs from the temperate climate of Hungary where the reference values for serum concentration of FT4, T3 and TSH used in Uganda were established. Differences between this study results and those reported by Fisher (1996) and Nelson et al. (2004), can be explained by the differences in race, climate and probably life style and diets.

This study like many others before shows no difference in serum concentration of FT4, T3 and TSH between males and females (Nelson et al., 1993; Fisher, 1996; Samollow et al., 2004; Fathzadeh et al., 2005). Although other studies had found that serum concentrations of FF4, T3 and TSH decrease with age (Yoshida et al., 1989; Nelson et al., 1993; Fisher, 1996; Myers et al., 2006), this study found no statistically significant change of these hormones with ages. Lack of significant variation in serum concentrations of these hormones with age in this study could be due to the narrow age range for the subjects (19-37 years). Even other researchers reporting on adults (20 - 50 years) found no significant change with age in serum T4, TSH, but modest decrease in T3 (Nelson et al., 1993; Delange \& Fisher, 1995; Fisher 1996). 
There was no relationship between students' origin and mean serum concentrations of FT4, T3 and TSH. This is due to the fact that all regions of Uganda are within the same (tropical) climatic condition. Another reason is the government policy whereby all table salts in the Ugandan markets are iodinated to supports easy formation of T3 and T4 in the population. This makes it possible to have iodinated salt in more than two-third of all households in Uganda.

Overweight (BMI $\left.25-29.9 \mathrm{~kg} / \mathrm{m}^{2}\right)$ and obese students $\left(>30 \mathrm{~kg} / \mathrm{m}^{2}\right)$, had average TSH above that of the students of normal BMI. This shows an increased TSH concentration with increased BMI. This finding is similar to those reported by other scholars (Knudsen et al. 2005; Bhowmick et al. 2007; Ortega et al. 2007). The lack of significant association between BMI and T4 and T3 levels as been reported by Manji et al. (2006). Yet in children T4 has been found to be significantly higher in obese children compared to those of normal weight (Bhowmick et al. 2007). A negative association between BMI, and T3 and T4 has been reported by Myers et al.(2006) while others showed that free T3 and free T4 concentrations being lower in obese women (Sari et al. 2003 ), which is in contrary to our findings.

The mechanism of increased TSH in overweight than normal students could be due to, a high level of leptin in overweight students than other group because TSH concentration is associated with percentage body fat and leptin concentration. Leptin which is produced mainly in the adipose tissue, in low doses cause increase in serum TSH concentration (Ortiga-Carvalho et al. 2002). It stimulates biosynthesis of Thyrotropin Releasing Hormone (TRH) and influences the activity of the hypothalamic- pituitary-thyroid axis (Nillni et al. 2000; Ortiga-Carvalho et al. 2002). Although plasma leptin levels were not determined in these subjects, the results indirectly suggest the fact that a possible association between leptin and the hypothalamic-pituitary-thyroid axis do exist.

In conclusion, the hormonal levels for Ugandans obtained from this study differ from the reference values which are currently used in the country. We therefore recommend a similar study involving bigger sample which is more representative of Ugandans to be conducted so as to establish normal reference values of T4, T3 and TSH for Ugandans. Since TSH was observed to increase with BMI, it is important that body mass index is taken into consideration during interpretation of serum TSH concentrations results.

\section{Acknowledgements}

The authors wish to thank Department of Medical Physiology of Makerere College of Health Sciences, for allowing the use of their Radioisotope Laboratory for this study. We also acknowledge Weill Bugando University College of Health Sciences, for partly sponsoring this study.

\section{Declaration of interest}

There is no conflict of interest that could be perceived as prejudicing the impartiality of the research reported.

Received 20 April 2009

Revised 28 October 2009

Accepted 28, 2009

\section{References}


Andersen, S., Pedersen, K.M., Bruun, N.H. \& Laurberg, P. (2002) Narrow individual variations in serum $\mathrm{T}(4)$ and $\mathrm{T}(3)$ in normal subjects: a clue to the understanding of subclinical thyroid disease. Journal of Clinical Endocrinology and Metabolism 87, 10681072.

Bhowmick, S.K., Dasari, G., Levens, K.L. \& Rettig, K.R. (2007) The Prevalence of Elevated Serum Thyroid-Stimulating Hormone in Childhood/Adolescent Obesity and of Autoimmune Thyroid Diseases in a Subgroup. Journal of the National Medical Association 9, 773 - 775.

Delange, F. \& Fisher, D.A. (1995) The Thyroid gland. In Clinical Pediatric Endocrinology. edn 3, pp 397-433. Ed CGD Brook. Oxford: Blackwell Scientific.

Fathzadeh, M., Seyedna, Y., Khazali, H., Sheidai, M. \& Farhud, D. (2005) Epidemiological Study of $\mathrm{T}_{4}, \mathrm{~T}_{3}$ and TSH Mean Concentrations in Four Iranian Populations. Iranian Journal of Public Health 34, 74-79.

Fisher, D.A. (1996) Physiological variations in Thyroid hormones: physiological and pathophysiological considerations. Journal of Clinical Chemistry 42, 135-139.

Hollowell, J.G., Staehling, N.W., Flanders, W.D., Hannon, W.H., Gunter, E.W., Spencer, C.A. \& Braverman, L.E. (2002) Serum TSH, T4, and thyroid antibodies in the United States population (1988 to 1994): National Health and Nutrition Examination Survey (NHANES III). Journal of Clinical Endocrinology and Metabolism 87, 489-499.

Knudsen, N., Laurberg, P., Rasmussen, L.B., Bu“low, I., Perrild, H., Ovesen, L. \& Jorgensen, T. (2005) Small Differences in Thyroid Function May Be Important for Body Mass Index and the Occurrence of Obesity in the Population. Journal of Clinical Endocrinology and Metabolism 90, 4019-4024.

Manji, M., Boelaert, K., Sheppard, M.C., Holdert, R.L., Gough, S.C. \& Franklyn, J.A. (2006) Lack of Association between serum TSH or free T4 and Body Mass Index in euthyroid subjects. Journal of Clinical Endocrinology 64, 125-128.

Meikle, A.W., Stringham, J.D., Woodward, M.G. \& Nelson, J.C. (1988) Hereditary and environmental influences on the variation of thyroid hormones in normal male twins. Journal of Clinical Endocrinology and Metabolism 66, 588-5892.

Myers, M.J., Rea, L.D. \& Atkinson, S. (2006) The effects of age, season and geographic region on thyroid hormones in Steller sea lions (Eumetopias jubatus). Comparative Biochemistry and Physiology. Part A, Molecular \& integrative Physiology. 145, 90-98.

Nelson, J.C., Clark, S.J., Borut, D.L., Tomei, R.T. \& Carlton, E.I. (1993) Age related changes in serum free Thyroxine during childhood and adolescence. Journal of Pediatrics 123, 899-905.

Nillni, E.A., Vaslet, C., Harris, M., Hollenberg, A., Bjorbaek, C. \& Flier, J.S. (2000) Leptin regulates prothyrotropin-releasing hormone biosynthesis: evidence for direct and indirect pathways. Journal of Biological Chemistry 275, 36124-36133.

Ortiga-Carvalho, T.M., Oliveira, K.J., Soares, B.A. \& Pazos-Moura, C.C. (2002) The role of leptin in the regulation of TSH secretion in the fed state: in vivo and in vitro studies. Journal of Endocrinology 174, 121-125.

Ortega, E., Pannacciulli, N., Bogardus, C. \& Krakoff, J. (2007) Plasma concentrations of free triiodothyronine predict weight change in euthyroid persons. American Journal of Clinical Nutrition 85, 440 - 445.

Reed, H.L. (2000) Environmental influences upon thyroid hormone regulation. In Werner and Ingbar's the thyroid. edn 8, pp 257-265. Eds LE Braverman \& R Utiger. Philadelphia: Lippincott-Raven. 
Samollow, P.B., Perez, G., Kammerer, C.M., Finegold, D., Zwartjes, P.W., Havill, L.M., Comuzzie, A.G., Mahaney, M.C., Goring, H.H., Blangero, J., Foley, T.P. \& Barmada, M.M. (2004) Genetic and Environmental Influences on Thyroid Hormone Variation in Mexican Americans. Journal of Clinical Endocrinology and Metabolism 89, 3276-3284.

Sari, R., Kemal, M., Balci, Altunbas, H., Karayalcin, U. (2003) The effect of body weight and weight loss on thyroid volume and function in obese women. Journal of Clinical Endocrinology 59, $258-262$.

Yoshida, Sato, M., Ohtoh, K., Cho, F. \& Honjo, S. (1989) Effects of aging on the in vivo release of thyrotropin (TSH), triiodothyronine, and thyroxine induced by TSHreleasing $\mathrm{T}$ hormone in the cynomolgus monkey (Macaca fascicularis). Journal of Endocrinology 124, 1287-1293. 